\title{
Construction of Humanities System in Ideological and Political Education
}

\author{
Jingying Jia \\ Yunnan University of Traditional Chinese Medicine, Kunming, Yunnan, 650500
}

Keywords: Humanities, Ideological and Political Education, Content System

\begin{abstract}
The essence of ideological and political education is a kind of social practice education that cultivates, shapes, transforms, develops and perfects people. It has extensive and profound humanities heritage. The fundamental purpose of the ideological and political education is to enable people to have a high level of ideological qualifications and noble character. Over a long time, however, people often neglect the important role of humanities in ideological and political education in colleges and universities. They fail to understand the important role of humanities in shaping, training and perfecting people. Based on the analysis of the connotation of humanities in ideological and political education in colleges and universities, this paper, in close connection with the current situation of humanities in current ideological and political education, focuses on the emerging problems and analyzes their causes in detail, and puts forward some countermeasures in order to improve the practicality of ideological and political education in colleges and universities. By studying and integrating the research of humanities and ideological and political education in colleges and universities, it is bound to stimulate the coordinated progress and common development of the two. It will also push for the ideological and political education in universities in a new era to a new level.
\end{abstract}

\section{Introduction}

At present, in university education, the loss of humanistic spirit and the predicament of humanistic education have gradually emerged. It is imminent to strengthen humanistic education. Some phenomena existing in the actual social education and school education lead us to think about the lack of humanistic education. The evaluation of students in real society and school is utilitarianism, which is full of commercial atmosphere, which is detrimental to, and even hinders the healthy growth of students' body, mind and intelligence. Undergraduates' humanistic accomplishments and humanistic sensibilities are neglected. The lively personality, the passion created and the persistent spirit are almost obliterated. The technical rationality replaces the humanistic spirit. The alienation of human beings can not be ignored. The enhancement of humane education, the reconstruction of humane spirit and the reconstruction of human spiritual home are endless, which fully reflects the loss of moral norms and the loss of humanistic value. In particular, it requires humanistic education and requires the conscious and re-awakening of humanistic spirit. Therefore, not only social science requires cultural heritage but also humanities, humanities, science and engineering, medical science, etc. All disciplines need cultural heritage and humanities education needs to be strengthened and humanistic spirit vigorously promoted. 'Only in the thinking of college students Humanistic education runs through the process of political education. Humanities in college students' ideological and political education are more vivid, more appropriate and more easily accepted by students.

\section{The practical significance of humanities in ideological and political education in colleges and universities}

Establishing a harmonious society of equality, mutual assistance and coordination has always been a beautiful pursuit of mankind. In order for society to develop in harmony, people who are the mainstay of development must first of all develop in harmony. To leave people's own harmonious development, the cause of harmonious development has lost its origin, the fundamental driving 
force and goal of the end. Harmony of the individual body and mind is the first level of harmony, is the micro level of harmony, but also the basis of harmony. Only with a harmonious moral personality, can someone and man, the harmony between man and nature, have left the harmony of self-mind and body, and the harmony between man and man and man and nature has become talk. A harmonious society should be full of creative vitality. To inspire people in all walks of life to create vitality, can not do without the motivational function of ideological and political education. However, the unity and mutual assistance, the good habits of helping the poor and the friendly and harmonious interpersonal environment based on the vitality-creating society depend more on the educational function of ideological and political education, while Humanities are the ideological and political education and education New point of view of human function.

The world is now moving towards diversification and integration of various cultures is inevitable. Under the impact of various cultures, how to treat one's own culture, how to inherit and carry forward one's own culture, draw on and absorb the foreign culture to carry on the cultural renewal and creation, make it have a long history and maintain the strong vitality An important issue. In the future pluralistic society, exchanges and cooperation between countries are getting closer and closer. In the information age, opportunities and ways for people to contact with foreign cultures have greatly increased. Students who are not properly guided can easily go astray and be influenced by undesirable cultures. Maintaining the sober mind of college students in a cultural and diversified society should not be fooled by the faux, vulgar and vulgar cultures, it is necessary to increase the students' humanities in ideological and political education, to educate and improve students with excellent traditional culture and values in the motherland Cultural quality, enhance the cultural recognition of college students and aesthetic taste.

\section{Analysis of the present situation of humanities in college ideological and political education}

At present, most undergraduates clearly recognize that adapting to an increasingly competitive society and becoming a useful person in society requires not only solid professional knowledge and skills but also good ideological and political qualifications, so that political education similar to "two courses" There is a state of positive need. In reality, in the teaching of ideological and political courses and in daily ideological and political work in colleges and universities, almost all teachers instilled into students are "positive" things. They talk about big truths, sing high-profile songs and conduct abstract but mostly empty preaching. New contradictions and new problems appearing in the process of reform, hot issues and sensitive issues that are of concern to students should be avoided if not explained clearly. Even if it involves occasional "dark side" things, it can not conduct a scientific and thorough analysis from the perspective of rational thinking, and can not solve some puzzles and deep-seated ideological problems in the students' thinking timely and effectively. Some of the contents of ideological and political education are outdated, so that students feel far away from the sense of life, educational content and reality there is a huge contrast. It is difficult to meet the needs of students, it is difficult to arouse the interest of students.

Because each student's social life conditions and the impact of education are not the same, because each student's knowledge accumulation and physical and mental development differences, especially the degree of their own subjective efforts are different, so there is ideological consciousness and morality with a certain difference, and showing a certain level. Especially with the expansion of enrollment in higher education institutions, the gradual transformation of university education from "elite education" to "mass education" has also made Dali's ideological and moral hierarchy more evident. This requires that ideological and political education in colleges and universities must proceed from the students' actual thinking, according to different levels of their thinking, treat differently and teach from person to person. However, in the eyes of the reality educators, all students have the same cognitive structure, without any difference and neglect the individuality and individual interests of the students. Therefore, in the process of education, they tend to emphasize "groups" and neglect "individuals" Engage in "one-size-fits-all" education, and do not teach people to carry out targeted education. 


\section{Effective ways of ideological and political education in colleges and universities}

The purpose of ideological and political education is to make people develop well and promote the healthy growth of people's virtue. Moral education itself is Yu Xin, Yude people and people's spiritual communication. Therefore, humane ideological and political education is based on student personality development and innovative spirit as the main purpose, the concept of cultivating innovative talents throughout the entire process of student management. We should use "human" means to understand the people, treat people, caring people, especially caring people's spiritual life and spiritual life. The establishment of this concept of "people-oriented" education can not be confined to the scope of ideological and political education. It should be carried out through the entire work of one school, penetrating into the hearts of all faculty members and making it the core of a school-running philosophy, so as to ensure that "Humanities" does not flow in words and forms. Moreover, the development of students should be regarded as the key standard to measure the work of ideological and political education, especially the development of individuality and creativity of students. The only way to create a good atmosphere of ideas.

Ideological and political education toward Humanities is aimed at college students and people-oriented is the meaning of the questions. Specifically speaking, we must take people as the starting point. We should fully respect and safeguard human rights and dignity. We should recognize and respect human differences in personality. We should be people-oriented, treat people with sincerity, and serve others rationally to recognize the individual's self-worth and try to satisfy people's reasonable and proper Interest demands, concerned about the vital interests of people. Really in the eyes of someone, someone in my heart, everything to people first, people-oriented, people-respect. The second is to believe in people. The ideological and political education toward Humanities fully affirms human nature, believes in the potential of human beings, and the potential wisdom of human beings and believes in the self-realization of human beings. In the process of ideological and political education, educators should act as facilitators, helpers, counselors, collaborators and even true friends of all-round development of students in an equal and democratic way to understand people, trust people and tolerant people. The third is to people for the purpose. Ideological and political education toward Humanities is not only a means of improving the humanistic quality of students, but also an aim of all-round development of students. In the ideological and political education, we must ensure the students' happiness and health, raise their awareness of health, create a harmonious social environment and good conditions to support their self-realization, and provide humane education and humane management to promote the all-round development of students.

Ideological and political education of college students involves all aspects of thinking, learning and living of college students, and their thoughts and behaviors subtly affect each student. This requires that college students' ideological and political education counselors must have excellent ideological and political qualities, possess the basic theoretical qualifications of Marxism-Leninism, be able to use the basic principles of Marxism-Leninism to analyze and solve problems, conscientiously uphold the party's basic line, principles and policies, in politics and ideology, they should be consistent with the party Central Committee. They should have correct world outlook, outlook on life and values, and always be concerned about the major national affairs. Understanding the situation at home and abroad can guide students to learn Marxism-Leninism, Mao Zedong Thought, Deng Xiaoping Theory and the important thinking of the 'Three Represents, Firm political positions and beliefs.

College ideological and political education counselors must be loyal to the cause of the party, full of enthusiasm and confidence in their work. From the cause of the party and the people, in order to cultivate talents to work as their own responsibility, dedication, become well-received by the student mentor To devote students passionate, in-depth classrooms, dormitories, canteens and students emotional exchanges Love students, respect Students, understanding and understanding of each student, comprehensive care for the healthy growth of students to be a teacher, take the lead in setting examples, requiring students to do, their first to do, to show noble "personality charm." Only in this way can infect students, educate students, become close friends of students, as their beacon 
of progress. In the process of modern education, counselors of college students' ideological and political education work is complicated, subtle and arduous, which requires that they have good physical fitness. The counselors of ideological and political education in college students must also have good psychological qualities, continuously strengthen the study of psychological knowledge, strengthen psychological training, master the law of psychological development, develop self-confidence and willpower, learn ways of psychological adjustment, and maintain an optimistic attitude. In the face of all the situations that occur among undergraduates, we should conscientiously investigate, handle with caution, deal with everything in a calm manner, embrace the mistakes of students with open-mindedness, and work in optimistic mood and humorous language.

\section{Conclusions}

Under the influence of the social environment, new problems are emerging in the study, life and even ideology of college students. Therefore, the college student ideological and political education counselors must have a wealth of college students ideological and political work experience and skills, can work handy. First, the ability to organize and coordinate. Counselors should be both educators and managers. They should have the ability to determine goals and plan specific goals, the ability to implement human, material and financial resources, and to make a comprehensive assessment of the pros and cons of work. Incident response ability. The second is the ability to express. Counselors should be good at using concise and tone of the narrative, so that students are easy to understand, willing to accept. Third, interpersonal skills. Counselors only have the ability to communicate with students in order to enhance their affinity with students and to carry out their work better. Fourth, observation ability. Excellent counselors should have keen observation skills, by observing the characteristics of students to understand the emotional state of students and psychological conditions, work predictably. The effectiveness of counselors depends not only on the scientific nature and relevance of educational content but also on the artistic, creative and flexible nature of education.

\section{References}

[1] Zhang Zhengrui. On the formation of the ideological and political education of the subjectivity [J]. Party Building and Ideological Education. 2017 (09)

[2] Lan Jiang. Questioning the subjective ideological and political education [J]. Ideological Education Research. 2005 (06)

[3] Hao Yanli. Analysis of ideological and political education based on subjectivity in colleges and universities [J]. Talent. 2014 (29)

[4] Shao Huanju. Construction of the ideological and political education work mechanism based on the subjectivity and diversity of students in colleges and universities [J]. Board and employment (Employment Edition) .2012 (01)

[5] Hu Huaiqing, Du Qinghua, Xu Ayu. On teachers in strengthening ideological and political education in the subjectivity [J]. Education Exploration .2005 (04) 